\title{
Developing Reading Skills and Beginning Writing through Literary Literacy
}

\author{
Rama Wijaya A. Rozak, Yeti Mulyati, Vismaia S. Damaianti, Sumiyadi \\ Indonesian University of Education \\ rapuza07@gmail.com
}

\begin{abstract}
Media in learning is very important to support learning success and maximize learning outcomes. In the multimedia era, the media used tend to be technology-based. But it is possible that conventional media such as books, novels, pictorial stories etc. can still be used and are indispensable. Literary work is very possible to be used in learning, especially in early reading and writing. Literary literacy by utilizing literary works can be chosen as a solution in learning, because literature has many advantages, including developing language skills, developing character, learning media, and others. The purpose of the study was to obtain a profile of reading and writing early learning in elementary schools in the city of Bandung. Data is used as a reference for designing learning syntax by utilizing literary literacy. Descriptive qualitative methods are used in research to analyze the data obtained. The main data used were teacher answers based on questionnaires distributed in 40 different elementary schools in the city of Bandung. Based on the results of the study, only a few teachers used literary works in reading and writing early learning. The use of literary works, especially fables has not been maximally utilized in learning. Whereas by utilizing literary works, teachers can develop language skills and student character, as well as social learning.
\end{abstract}

Keywords-Early Reading and Writing Early Reading and Writing Ability, Literary Literacy, Literary Works, Fables in Early Reading and Writing.

\section{INTRODUCTION}

In this millennial era, education or more precisely learning is required to be packed with fun and contemporary, for example by using multimedia. Discuss multimedia will tend to utilize media technology, for example laptop, internet, projector, etc. This happens because it is associated with the development of a modern era of technology. In fact, a book, novels, short stories, articles can also be used as a medium of learning. These media are still frequently used because of the availability and easy way of obtaining. Teachers can create media independently with their own creativity. Unlike when using media technology, not all schools have adequate facilities and infrastructure.

The inequality of dissemination and utilization of technology is still felt in this millennial era. However, if scapegoating technology as a difference in students' abilities, it cannot be justified. Schools that do not have the technological means can take advantage of the media that teachers can easily find and create. Thus, students can still compete without the use of technology, especially in terms of reading and writing beginning or can be referred to as micro literacy. Mulyati (2016a, p. 509) explains that "Micro literacy can be interpreted as literacy as the basis for more functional and implementative abilities." Literacy interpreted as a literacy activity, it is in line with the learning to read writing the beginning for low-grade students. Thus, literacy can also be interpreted as literacy which is of course the main target is the learner in the lower classes that is between 1-3 grade of elementary school. The ability to read and write is a basic ability that must be mastered by students, because with the ability to read and write a qualified, will enable students to gain knowledge. Nuryani (2016, p. 161) explains that "Reading is a language skill, a person who likes reading may have better language skills, as well as his knowledge". Nationally, today is being intensively socialized school literacy movement as mandated by regulation of the minister education and culture number 23 of 2015, on the Growing of Character" (Mulyati, 2016a, p 507).

Based on the results of the EGRA-SSME research that was launched in ACDP Indonesia (2014, p. 6) with the theme "The Importance of Reading and Assessment in Early Classes" shows that the ability of reading elementary school students in Indonesia is still very low.

A second assessment, conducted on 4,812 2nd grade students, showed that less than half of the children were adept at reading and understood (redefined as, able to answer at least 4 out of 5 questions correctly). A total of $26 \%$ can answer 3 of 5 statements correctly and $5.8 \%$ of students cannot read at all.

The study was conducted in 400 elementary school/Madrasah throughout Indonesia conducted by USAID America, RTI International in collaboration with education ministry, and Myriad Research. Based on the data, it can be concluded that the reading ability of elementary students in Indonesia is still very low. Though the ability to read and write 
is needed by students to develop the ability of others. This is explained by Mulyati (2016b, p. 975) in her writings "Early literacy acquisition through early school reading and writing, especially in grade I primary school, is a very important and strategic phase of the child's life". The results of EGRA-SSME and other studies having an impact on learning to read and write the beginning should produce a qualified outcome.

This fact becomes a challenge for educators and researchers to provide attractive packaging in learning and able to develop students' reading and writing skills. It is time for the reading and writing lessons to be given the values of innovation but do not undo the local wisdom of Indonesian culture, among them by utilizing the media of literary works (fables). Literature (fable) is chosen because of the content of the good that is in it, and the concerns about literature that began to be forgotten in learning. As described by Emzir \& Rohman (2015, p. 226) "Older literature research and learning for students in schools today is an empty field that needs more serious cultivation that calls for the participation of all parties" Whereas the direction of literary teaching policy is expressly stated in regulation of the minister national education number 22 year 2006 concerning content standard for elementary and secondary education unit. It is explained that the purpose of literary tuition so that learners have the ability (1) to enjoy and utilize literary works to broaden the insight, refine the character, and improve the knowledge and language skills, and; (2) to appreciate and develop Indonesian literature as the cultural and intellectual treasures of Indonesian people.

The current condition of literary learning should receive better attention in the community as well as in the school as a means of learning. Slowly but surely, literary works began to lose interest in the community. "It is very worrying when the learning of literature begins to disappear because of the technological advancement" (Sumaryana, 2017, p. 21). Furthermore, Sumaryana (2017, p.22) explains that "In primary school, literature learning should be the first milestone of students in understanding literature, starting from children's literature, adolescent literature, to adult literature". Based on these explanations can be imagined the importance of literary learning in schools and the importance of a literary work for the development of students' abilities.

The solution to developing children's reading and writing skills is to provide and familiarize literature literature early on by selecting appropriate stories. This is further explained by Ampera (2010, p. 9).

... children live in a period of rapid development, especially physical and mental development. To support the physical and mental development of children, literature can be used as a supporting tool, because literature can

provide high values for the development of language, cognitive, personality, and social of children.

Literary works is a way out to make changes and planting the character of students. "Literature has great potential in bringing society toward change, including changes in one's character" (Aminuddin 2002, p. 31). It is understood that literature can be used to teach the language and hone students' social skills with the content contained in a literary work. Means in one learning can provide two benefits at once with the presence of literature.

\section{METHODS}

The study used a descriptive qualitative method that focused the analysis of the data obtained, namely questionnaire data. Bogdan (1982, p. 27-29) describes the characteristics of qualitative research, namely, 1) using the natural environment as a source of direct data, 2) descriptive analytical nature, 3) research pressure on the process not on results, 4) inductive nature, and 5) prioritizing meaning. Primary data comes from questionnaires distributed to elementary teachers in 40 different schools in the city of Bandung. Data were analyzed to find out the profile of reading and writing early learning carried out by the teacher and the use of literary works in learning. Then the results of the analysis are used to formulate the design of reading and writing early learning based on literary literacy.

\section{Description of the Learning Reading and Beginning Writing in School}

\section{FINDING AND DISCUSSION}

Learning to read is a complex learning, as well as other language skills, listening, speaking, and writing (Rozak, 2014 , p. 125). In reading or reading, many aspects of the reader are involved, just like any other language skills. Aspects involved in reading activities, among others, the level of reader intelligence, the ability of the eye in view writing, the ability to concentrate on reading, experience and knowledge readers, memory in reading recall, techniques in reading, and others.

Learning to read in primary schools is focused on literacy and able to write the language symbols. This activity is known as learning to read and write the beginning. Early reading and writing lessons are given to low-grade students (grades 1-3). It has been mentioned earlier that the main objective in learning to read and write the beginning is to introduce letters, read syllables, read the word, and come to the complex that is reading a simple sentence. In addition, students are guided/taught to write the language symbols they read or which they (students) say.

In an effort to find out the profile of learning to read and write the beginning in schools, observation and questionnaires were distributed to 40 first grade teachers at different schools in Bandung. Based on the results of the 
questionnaire obtained a picture of learning to read and write the beginning of the implemented by the teacher. Basically there is no best method of learning, it is reflected in the use of diverse methods in learning to read and write the beginning.

Based on the questionnaire analysis data obtained a conclusion that the teacher has not utilized literary works in learning to read and write the beginning. Since the first, literature is considered to be a solution in character learning, but in practice in the field shows that literature has not been able to be utilized optimally in learning. The teacher separates literary learning from language learning. Understanding like this is widely believed by the teacher so it is not strange if more and more students do not like literature, because the portion of literary learning is very little compared to language learning. In addition, it is aggravated by the state of the field that few teachers like literature and literary literature. So do not be surprised if the learning of literature is seen as a boring learning. It should begin to grow awareness that literary learning is not a separate part of the language, but both are integral parts that cannot be separated.

Teacher must begin to build awareness that literature can develop character, honing ethics, manners, acquisition of language and others. Language learning should begin with a literary work. In a literary work contained the various goodness needed by the learner including the acquisition of vocabulary. At that time, literary works can develop students' imagination, because students can play with their own imagination. The impact of accompaniment of it is that it can reduce the dependence of students/children on technology that is now very developed and become a prima donna. If language learning is based on literary works, it is not impossible that the student will behave like a decent Indonesian.

\section{Fable Literature in Developing Reading Ability and Beginning Writing}

Literary works are very possible to be used with the maximum in developing the ability to read and write the beginning. Fable is an old piece of literature (tale) that is rarely found again in a lesson. In fact, fables can be used in developing students' language skills, namely listening, speaking, reading, and writing. In addition, the school literacy movement promoted by the government has not been able to be optimized. Students tend to read for themselves instead of being read/taught by the teacher. It is time for literature to take its role back in the world of school and social life of students.

In a literary work it has many virtues, as described by Tarigan $(1995$, p. 10) "... the benefits of literature in children's education, among others; 1) language development, 2) cognitive development, 3) personality development, and 4) social development ". This is affirmed by Kosasih (2013, p.222) in his writings "From a story, students are not only entertained, but didactic values that can shape their character, religiously, family, or society". It is very clear that literary works especially fables can provide positive developments to students. Fables can be used to develop students 'reading and writing skills, in addition, can also develop students' ethics and morals in a better direction.

The moral and ethical development of students can be improved by the media of literary works of fables. In a literary work contained positive values that can be used as teaching and learning. Literary works is a complete package medium that can be recommended in learning to read and write in low class. Positive values in literary works are expressed by Noor (2011, p. 51-52) "there are six fairy-tale benefits for children: 1) teach good moral values; 2) develop children's imagination; 3) add insight; 4) increase creativity; 5) bringing children closer to parents; and 6) eliminating tension or stress ". Of course in this case the teacher must work with parents of students. "The obligation of parents and literary teachers to determine the literary choice that is in accordance with the soul of the child, the literature that places the child as the main observer and as the center of the owner needs to gain experience and develop his fantasy" (Ampera, 2010, p. 9). Parents should play an active role in giving the fairy tales to their children at home. Thus, all elements of society must be able to create a friendly atmosphere of literature, so that all forms of goodness in the literary work not only change the students, but also change the community to a better direction.

Based on the explanation can be understood that the literary work is a way out for the development of students in the multimedia era today. In order to succeed it must be designed an integrated learning steps with literature. The following syntax describes learning to read and write the beginning by using literary works of fable.

\section{Listening to Student Stories}

This learning phase aims to collect various stories obtained from students. This learning phase is in accordance with the Language Experience Approach (LEA). The purpose of listening to students' stories is that teachers can formulate the most appropriate fable stories to tell students, so that students will feel close to the tales that have been formulated by the teacher. The element of story closeness with students will have an impact on students 'acceptance of the story and foster interest in students' learning and imagination. 


\section{Creating a Fairytale Manuscript}

Based on the stories learned from the students, the teacher formulated the story into a fairy tale. The expertise of teachers in making the tale script is crucial to the success of learning. In formulating the tale script many things to be considered, including the legibility of manuscripts, the suitability of the text with the development of psychology of learners, treasury and student vocabulary development, and others. In other words, teachers can not formulate and create random texts randomly. Preparation of fable stories in accordance with the development of learners will foster interest in reading students. Then it can develop students' social abilities. Therefore, teachers must be truly selective in compiling and giving fable stories.

\section{Tale with Big Book or Puppet media}

After the script is made, the teacher tells the story by exerting its ability to tell the story to the students. Teachers do not just read a fairy tale, but must be able to deliver the fairy tale to appeal to students. In the process of storytelling, teachers must follow the rules in reading fairy tales, for example the way of reading, gestures, facial expressions, etc. to optimize the delivery of stories to students. Expressive delivery of stories will be much better than the usual fairy tales (like reading a script). Therefore, it is not just fable stories that must be qualified, but also the way of telling the story to be maximized. In storytelling, teachers can use the big book media to add story appeal. Big book is literally meaning, the book used is large so it is seen by all students. Books can be $60 \mathrm{~cm} \mathrm{x} 45 \mathrm{~cm}$ in length. Big book media is the result of creativity from the teacher, the more creative the bigger the big book will be made. In addition to the big book media, teachers can use the puppet as a medium for storytelling to students. Big book or puppet can be used to maximize the learning process.

\section{Discussion}

In the process of discussion will stimulate students' ability in listening to stories and express opinions. Of course there will be diversity of opinions from students, the task of teachers is to guide students into a proper pattern of thinking. The most important thing in this stage is, teachers are forbidden to blame the opinions of students, because it will affect the psychological development, avoid the words negation. It is feared that the student will not dare to appear again in expressing opinions. In addition, the diversity of opinions that may occur will bring the class up, as it has many points of view to think. In this discussion will show students acceptance of the fable that has been made and the delivery of fable stories by teachers. The diversity of answers is a critical thinking pattern, because each student has his or her own point of view in thinking. Critical thinking process should be familiarized early on, because of these thinking patterns will emerge ideas that can provide solutions.

\section{Master Writing}

After the discussion process of characters and characterizations in the fairy tale, the teacher went on writing activities. The teacher writes the words and/or sentences contained in a fairy tale to be read together with the students. This writing activity is important, because the teacher will practice with students how to write a letter into a word and assemble it into a whole sentence. From that process, students will understand that what they write can be a language symbol and can be preached. In the process of writing, the teacher exemplifies slowly so that students understand that every stroke created can be interpreted as a language symbol.

\section{Reading Together and Individuals}

After the teacher finishes writing, the teacher asks the students to read together. In the reading activity together, the teacher also guides the students so that all students follow the learning stage. The reading process is done repeatedly with emphasis on letters or words that are considered difficult. The process of reading together is done by the method of SAS (Structure Analysis Synthetic) that is, first displayed one sentence, then divided into words, to the smallest part of the letter. Then do the opposite, from the letters arranged into a word and to a sentence. In reading activities, teachers allow students to learn to read alternately, so not all of them are read together. In the process of reading, students will understand by itself that written/they write can be a tool of communication/language tool. In addition to growing interest in reading, it can also foster students' interest to write.

\section{Write Together}

The teacher guides the students to write letter by letter until it is strung together into a word and to the sentence. The teacher invites students to write interchangeably until all students get the same part. This stage is to hone the students' ability in writing the language symbols so they can be read. Students should be aware that what they say can be written into a language symbol. From that point on, there will grow interest in writing and improving writing. 


\section{Rereading}

Rereading is the last stage in reading and beginning writing learning by strengthening literary literature. Rereading is meant for habituation to the students to love reading, especially those they read are their own writing (no longer teacher writing). From this it is expected to grow the motivation of reading and writing that they write can be read.

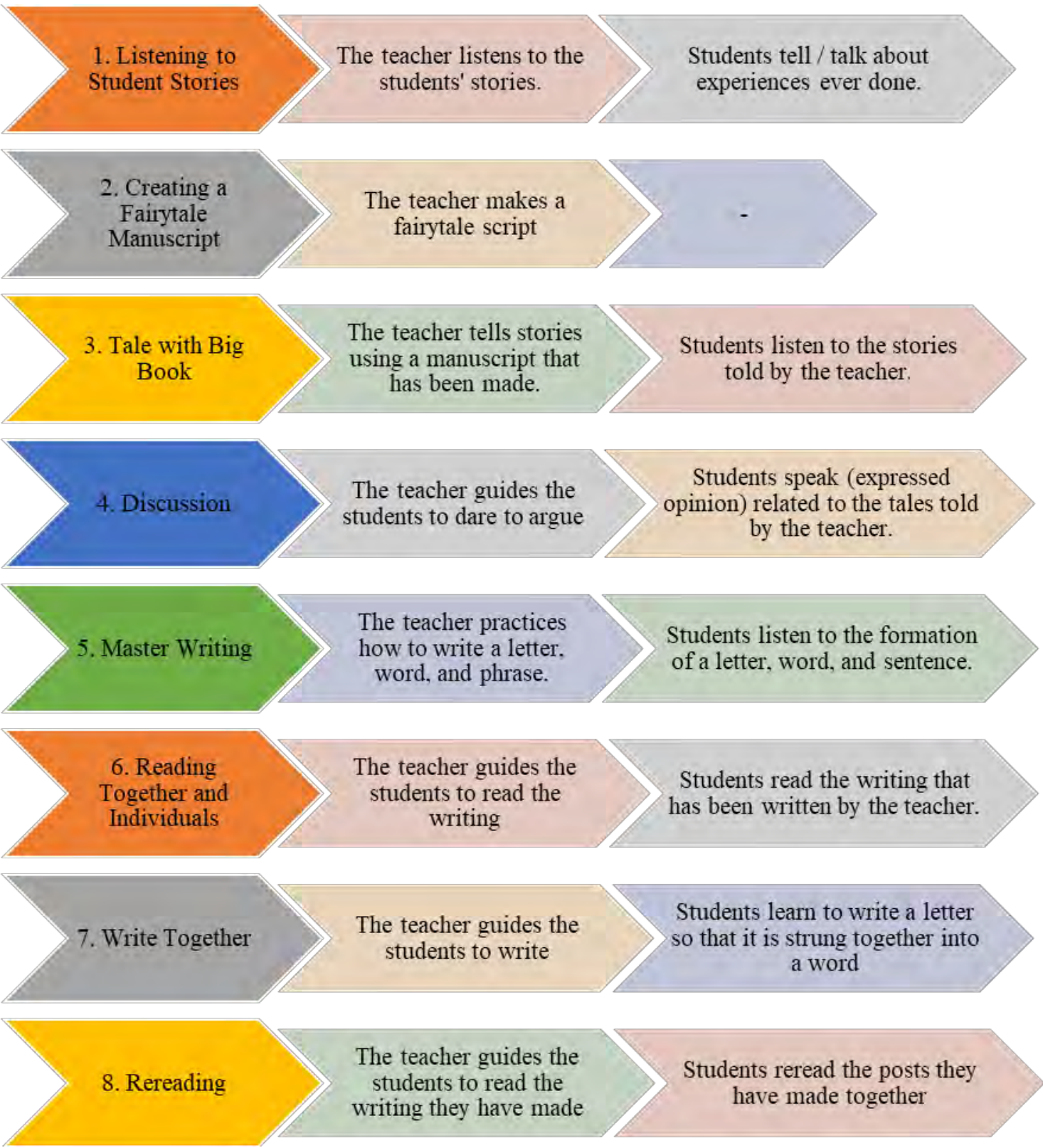

\section{Figure 1}

\section{Syntax and Learning Activity Reading and Beginning Writing through} Literary Literature

Based on the explanation of the learning stages, it can be understood that the learning takes place using literary works by utilizing the media fable. From the discussion can be understood also that the literary work is very capable to be utilized in language learning. So, eliminate the notion that literature is a separate part of language/language learning, so the 
paradigm of Indonesian learning can be changed. The change in question is that there is no more attachment/separation between language learning and literary learning in schools at various levels.

\section{CONCLUSION}

Literacy is something that is being discussed today. Literacy is considered capable of improving the quality of a person, society, and even his country. Indonesia is declining in its literacy based on the results of researches, especially the results of EGRA-SSME research. On the basis of that, the government launched the School Literacy Movement to improve the culture of 'read-write' early on. Literacy, especially literary literature, can be used as a reinforcement in learning, especially in early reading and writing lessons. Media literary works can provide two advantages at once, namely education on ethics, morals, and character, and can be used as material to teach the language. Thus, literary literature (fable) is an alternative to improving the character of students, developing character, and ending the moral degradation problems that plagued Indonesia, as well as developing aspects of students' language skills.

Literary literature can also be used as a medium to support the movement of school literacy proclaimed by the government. Literature text-based literature also offers a solution to the variation of text in supporting the ability to read and write low-grade students. Psychologically low class students have a very strong imagination power so that the use of literature as a literacy material will be very effective. That is, not only on the expression of the ability to read and write but also in the areas of cognitive development, affective, even possible to psychomotor. Creative teachers should be supported by high literacy skills that can give birth or create literate students.

Based on the designed syntax, the use of literary works can be done in learning. In addition, the advantages derived from the use of literary works are integrated learning between the ability to listen, speak, read, and write. Using fable literary works can sharpen and improve four language skills simultaneously in one lesson. Imagine if every literary work is used in a lesson, it is not impossible that Indonesian students will be more literate. Then, the most important thing about literature is full of meaning and advice for its readers. Since the first literary works considered as a solution to the forming of character, ethics, morals, and the development of imagination. Means, in addition to improving the cognitive domain, literary works can improve the social sphere of students. In the utilization of one media (literary works) obtained various advantages that accompany it. This article is a literature review study, the primary data used on the basis of questionnaire analysis. From the results of the analysis designed a learning solution that is poured in the learning syntax. Syntax designed to utilize media fiction literature that is very easy to find and found in various print mass media and online. A field research is needed to prove the suitability and efficacy of the solutions that have been designed. Field research will be an excellent consideration for developing syntax that has been designed based on theoretical studies.

In addition, to optimize the syntax that has been designed, the teacher can add a snapshot (picture story) taped to the classroom wall. Utilization of the picture story aims to foster interest in reading students. The selected picture story is still related to the fable used as an reading and writing beginning learning medium. Picture story attached to the wall can be assigned to students as a read work. Then to be more interesting, the sticking of these picture story used a treasure trove system. That is to say, one story in picture story is taped to a different location/wall with symbols (numbers) in each story. It can be used to play as well as learn by the students. The picture story is replaced with a certain period by the teacher, when all students have read it.

\section{References}

ACDP Indonesia. (2014). Pentingnya membaca dan penilaian di kelas-kelas awal. [Online]. Tersedia:http://www.acdpindonesia.org/wp-content/uploads/2015/02/Working-Paper-ACDP-EGRA-Indonesia-FINAL1.pdf. Diakses 15 Februari 2017.

Aminuddin. (2002). Pengantar apresiasi karya sastra. Bandung: Sinar Baru.

Ampera, T. (2010). Pengajaran sastra: Teknik mengajar sastra anak berbasis aktivitas. Widya Padjadjaran: Bandung.

Bogdan, B. (1982). Qualitative research for education: an introduction to theory and methods. Sydney: Allyn and Bacon, Inc.

Emzir \& Rohman, S. (2015). Teori dan pengajaran sastra. Raja Grafindo Persada: Jakarta.

Kosasih, E. (2013). Sastra klasik sebagai wahana efektif dalam pengembangan pendidikan karakter. Jurnal Pendidikan Bahasa dan Sastra Indonesia, Vol. 13 No. 2 . hlm. 225-236. [Online]. Tersedia: http://ejournal.upi.edu/ index.php/BS-JPBS/article/view/294. Diakses 5 Juni 2017.

Mulyati,Y. (2016a). Membangun dan meningkatkan kemampuan siswa dalam literasi melalui pembiasaan dan pembelajaran. Dalam Endang, D., dkk. (Penyunting), Prosiding Seminar Nasional dan Kongres Ke-3 Ikatan Pengajar Bahasa Indonesia (IPBI) Universitas Swadaya Gunung Jati (507-515). Cirebon: FKIP Unswagati Press. 
Mulyati, Y. (2016b). Pemanfaatan LEA berbasis big book dalam pembelajaran literasi awal. Dalam Sumiyadi, dkk. (Penyunting), Prosiding Seminar Internasional Rksa Bahasa X Universitas Pendidikan Indonesia (975-982). Bandung: UPI Press.

Noor, R. (2011). Pendidikan karakter berbasis sastra. Jogjakarta: Ar-ruzz Media.

Nuryani, R. (2016). Gerakan literasi sekolah meningkatkan kualitas bangsa. Dalam Endang, D., dkk. (Penyunting), Prosiding Seminar Nasional dan Kongres Ke-3 Ikatan Pengajar Bahasa Indonesia (IPBI) Universitas Swadaya Gunung Jati (161-168). Cirebon: FKIP Unswagati Press.

Permendiknas No. 22 tahun 2006 tentang Standar Isi untuk Satuan Pendidikan Dasar dan Menengah.

Rozak, R. W. A. (2014). Pendekatan kooperatif berorientasi hypnoteaching dalam pembelajaran membaca kritis siswa kelas VII. (Tesis). Sekolah Pascasarjana, Universitas Pendidikan Indonesia.

Sumaryana, Y. (2017). Pembelajaran sastra di sekolah dasar berbasis kearifan lokal (cerita rakyat). Jurnal Mimbar Sekolah Dasar, 4 (1), hlm. 21-28. [Online]. Tersedia: http://doi.org/10.23819/mimbar-sd.v4i1.5050. Diakses 5 Juni 2017.

Tarigan, H. G. (1995). Dasar-dasar psikosastra. Bandung: Angkasa. 